\title{
A Study Policy Implementation of Waste Management in Konawe Regency-Indonesia
}

\author{
Muhammad Amir ${ }^{1} \&$ Rola Pola Anto ${ }^{2}$ \\ ${ }^{1}$ Faculty of Administration Science, Halu Oleo University, Kendari, Southeast Sulawesi, Indonesia \\ ${ }^{2}$ Faculty of Administration Science, Lakidende University, Unaaha, Southeast Sulawesi, Indonesia \\ Correspondence: Muhammad Amir, Faculty of Administration Science, Halu Oleo University, Kendari, \\ Southeast Sulawesi, 93132, Indonesia. E-mail: amir_fisipuh@gmail.com
}

\author{
Received: October 3, $2017 \quad$ Accepted: October 23, $2017 \quad$ Online Published: January 30, 2018 \\ doi:10.5539/jsd.v11n1p90 URL: https://doi.org/10.5539/jsd.v11n1p90
}

\begin{abstract}
The purpose of this research is to analyze the policy implementation of waste management in Konawe Regency. The dimension of this research refers to the dimensions of communication, resources, disposition and bureaucracy structure to determine the effectiveness of policy implementation according Edward III (1980). This study also analyzes the obstacles in the implementation of management policy in Konawe District to find out the cause of unsuccessful waste management in Konawe District. Analysis policy implementation of waste management in Konawe Regency using qualitative approach. With the technique of collecting research data using in-depth interview, document study and observation. The result of this research concluded that the policy implementation of waste management in Konawe Regency viewed from communication, resources, disposition and bureaucracy structure aspect has been implemented by Environment Office of Konawe Regency. This study finds that there are still obstacles in the policy implementation of waste management in Konawe Regency is from the aspect of the facility is still lacking, the condition of the work area is very wide, the public awareness is still lacking, the community participation is still lacking, and the public knowledge about waste management is still minimal. The research findings proved that the policy implementation of waste management in Konawe Regency which aims to realize cleanliness, public health and better environmental quality can not be realized as expected, but waste management still needs hard work.
\end{abstract}

Keywords: policy, implementation, waste management, Konawe Regency, Indonesia

\section{Introduction}

Waste management policy in Indonesia pursuant to Law of Republic of Indonesia Number 18 Year 2008 about Waste Management. While waste management policy in Konawe Regency is based at Regional Regulation of Konawe Regency Number 30 Year 2015 about Waste Management. The policy objective is to improve hygiene, public health and environmental quality. Implementation of waste management policies in Konawe District from 2015 to 2017.

Before Konawe Regency Government made a policy in the form of local regulations on waste management, the waste management is not effective because it is still merged with the Public Works Department of Konawe Regency. In some waste dumps there are still many that accumulate and decompose due to late collected, transported and disposed, especially in the capital region of Konawe Regency in Unaaha, Tongauna, Wawotobi and Uepai districts. Waste originating from households, traditional markets, supermarkets, shops, offices and industry is not all that can be transported due to the limitations of waste trucks. By 2015 the volume of waste that can be collected and transported daily averages $128 \mathrm{M} 3$, while un-transported waste to the final waste dump is still close to $72 \mathrm{M} 3$. This is due to the limited number of waste transportation vehicles and the limited time of waste transportation. Each waste car can only carry trash to a final dump of $16 \mathrm{M} 3$ / day. In addition, the landfill is far enough away so the time spent on the journey is considerable. Every waste car only works until 11:00 noon. Car waste available only 8 units. Condition of a car that is fit to use 6 units and 2 units in poor condition (old) or not feasible to use.

The phenomenon of waste management in Konawe Regency has not been effective because it is not supported by government policy as the basis for waste management to work properly, efficiently and effectively. Along 
with the increasing volume of waste every day tends to reach $250 \mathrm{M}^{3}$ / day, then in 2015 Konawe Regency Government make waste management policy. Government policies on waste management provide the basis for the government to perform better, professional and effective waste management in order to achieve better hygiene, environmental health and environmental quality. Policy implementation of waste management is the responsibility of Environment Department of Konawe Regency.

After entering the second year, policy implementation of waste management in Konawe Regency has not been successful in accordance with the expectations of the government and the community. This is due to lack of supporting facilities such as waste car only 8 units. The increasing volume of waste is increasing due to the influence of the population, the economic activities of people in traditional markets, supermarkets, shops, housing, offices, households and households, and the increasing urbanization which has the potential to cause waste problems.

Empirically, the volume of waste in Konawe Regency is increasing due to the influence of the population of 2015 as much as 233,610 people (Statistics of Konawe Regency, 2015). In addition, due to urbanization factors that affect the problem of cleanliness, public health and the environment of the capital city Konawe Regency. These conditions also occur in all countries. Research Amasuomo and Baird (2016) in Nigeria finding that factors such as population increase and the coming together of people to form communities lead to increase waste generation. Research results Jalil (2010) in Malaysia reported that "as the population is increasing especially in urban areas; the volume of solid waste also increasing in developing countries including Malaysia. Study results Manaf et.al, (2008) in Malaysia find that "solid waste management is an integral part of urban and environmental management of each city". Study results Velumani, et.al., (2009) di India reported that "It also happens in some in India that Municipal Solid Waste (MSW) Management continues to remain as one of the most challenging task in urban development at India".

Research Ezebilo \& Animasaun (2011) in Nigeria finding that "waste management is done by the government as a result of urban development, such as the study has been conducted in a rapidly growing city in a developing country where solid waste management has been a major cause of concern. Although, various agencies have been established to manage municipal solid waste in Ilorin, southwest Nigeria they have not been very successful". Research result Ikhlayel et al. (2016) in North Africa find that "a similar phenomenon shows that, Municipal solid waste management (MSWM) is considered one of the challenging environmental problems in the Middle East and North Africa (MENA) region. Municipal solid waste increased significantly due to rapid population growth and fast urbanization, change in lifestyles and consumption patterns". Research Moersid (2004) in Indonesia find that more and more people will cause problems in the management of waste, the behavior and lifestyle of the community still tends to lead to the increase of waste generation rate which is very burdensome for cleaner management, limited resources, budget, personnel vehicle so the cleaners able to serve all the waste generated.

The research findings in several countries, proving that the increasing volume of waste as a result of increasing population, urbanization and economic activity. Thus, one of the reasons for the need for a waste management policy in Konawe Regency is the growing population and urbanization every year that can lead to waste in places such as from settlements, traditional markets, supermarkets, shops, home industries, offices. Research result Singh, et. al, (2014) ini Nepal finding that "rapid economic and population growth experienced in last decade has brought significant increase in amount of urban waste generation in many developing countries like Nepal. Increasing waste generation created many problems including littering and dumping in and around outskirts of urban areas. Main problems associated with waste management in most developing countries are 1) low waste collection rates, 2) low recycling levels (recycling limited to informal recyclers), 3) littering, and 4) inappropriate final disposal.

Policy implementation of waste management in Konawe Regency faces obstacles from the aspect of residential areas that have not adequate facilities such as roads in the asphalt and waste is still minimal. Barriers in waste management are also found in some countries that are policy implementation of waste management. This is relevant study result Onu, et.al. (2014) in Nigeria finding that "these unplanned settlements usually do not have good paved roads and are built haphazardly. This characteristic is the same in most Niger Delta settlements and cities in other regions of Nigeria. This unplanned nature of the settlements in the region as well as the absence of Waste Management (WM), facilities have hindered WM agencies and companies to adequately collect, transport and dispose of the wastes generated from these places. This situation has led to the unabated problem of indiscriminate waste disposal, inadequate waste collection and general waste management processes. Research result Nuzuli, et.al. (2015) in Banjarbaru (Indonesia) find that "basically waste management is the collection, transport, processing, recycling, or disposal of waste materials. Waste management methods vary depending on 
many things, including the type of waste substances, land use, and availability of area. Waste management is a process with two objectives, namely: turning waste into a material that has economic value, or processing waste to be a material that is not harmful to the environment. Therefore, Banjarbaru has a waste management system called Waste Bank Society (WBS)".

Policy implementation of waste management Konawe Regency aims to realize more effective waste management to create better hygiene, public health and environmental quality. Research result Muchangos, et. al, (2015) in Mozambique reported that a waste management policy is the core element of a waste management plan because it reflects the plan's goals and objectives to ensure responsible, coherent, effective, and environmentally sound waste management. Maputo City In Mozambique as a country's representative city, is in the process of establishing, implementing and expanding a quite comprehensive waste management policy framework. However, the gap between the intended and the current waste management situation is significant, and barriers do exist within key policy instruments.

Based on the phenomenon of waste management in Konawe Regency, the this research purpose is to analyze the policy implementation of waste management in Konawe Regency, focusing on the aspects of communication, resources, attitudes and bureaucratic structure. In addition, it also focuses on the aspects of obstacles in the policy implementation of waste management in Konawe Regency.

\section{Literature Review}

\subsection{Public Policy}

Public policies are those policies developed by governmental bodies and officials (Anderson, 2007 quote Winarno, 2007). Public policy is the authoritative allocation of values for the whole society (David Easton quote Thoha (2002). Furthermore, public policy is a proposed course of action of a person, group, or government within a given environment providing obstacles and opportunities which the policy was proposed to utilize and overcome in an effort to reach a goal or realize an objective or purpose (Friedrick quote Winarno (2007). Public policy is whatever governments choose to do or not to do (Dye, 2005; quote Winarno, 2007). Public policy is a set of interconnected choices made by agencies or government officials in areas pertaining to government tasks, such as defense of security, energy, health, education, public welfare, crime, urban and others (Dunn, 1994 ). Public policy is binding decisions for the people at the strategic level or outline made by the public authorities (Winarno, 2007).

Essence of expert opinion, that public policy is the authority of the government or a leader in government institutions to take action or not take action to achieve certain goals in the life of society, nation or country. Public policy is important in achieving goals in government institutions. Without any public policy made by the government, the objectives of the organization in government institutions will be difficult to achieve. Public policy is not only a decision or a choice taken by the government but public policy is the basis for government to act and is binding for the holder of power and even the public as the main target of the content of public policy.

\subsection{Policy Implementation}

Implementation as "getting the job done" dan "doing it" (Charles O. Jones,1991; cited Wahab, 2008). Implementation is the carrying out of basic policy decision, usually incorporated in a statute but wich can also take the form of important executives orders or court decision. Ideally, that decision identifies the problem(s) to be pursued, and, in a vaiety of ways, 'structures' the implementation process (Mazmanian and Sabatier, 1983). Implementation as to carry out, accomplish, fulfill, pruduce, complete. Implementation as a process and an output. The success of a policy implementation can be measured or seen from the process and the achievement of the goal of the final result of achieving or not achieving the goals to be achieved (Pressman and Wildavsky, 1978; cited Tachjan, 2008). Further, implementation is the implementation of policy making in other ways. The administrator's job is to implement policies formulated by policy makers (Parsons, 2005).

That policy implementation is viewed as a process or a flow. Policy Implementation is the implementation of basic policy decisions, usually in the form of law, but can also take the form of important executive orders or decisions or judicial decisions (Mazmanian dan Sabatier, 1983); cited Nugroho, 2014). Implementation of policies is seen as a process or flow. The process of policy implementation of the policy process from the perspective of social and political change, where the policy made by the government aims to make improvements or changes in society as a target group (Adam Smith, 1973 cited Islamy, 2001). Effectiveness of the implementation of a policy is determined by: (1) bureaucratic behavior of the executor. (2) the policy environment; (3) implementation requires institutional mechanisms and procedures; (4) implementers of consistent basic measures and policy objectives; and (5) demand innovation from implementers (Winarno, 
2007).

Policy Implementation as acts committed by individuals or officials or government or private groups directed at achieving the objectives outlined in the policy decision (Van Meter and Van Horn (1975; quote Nugroho (2014). Policy implementation is a way for a policy to achieve its objectives. There are two options that must be implemented directly in the form of a program or through a derivate policy formulation as a derivative of that policy (Nugroho, 2014). Elements of the policy implementation must be absolute: (1) the implementing element, (2) the existence of the implemented program, and (3) the target group or target group (Tachjan, 2008).

There are Six variables that affect the implementation performance, namely: (1) Size and policy objectives; (2) Resources; (3) Communication between organizations and the strengthening of activities; (4) Characteristics of implementing agents; (5) Social, political and economic conditions; and (6) Disposition of the implementor (Van Metter and Van Horn, 1975; cited Nugroho 2014). Factors that influence the implementation of the policy are: (1) easy or not the problem to be worked on, (2) the ability of the policy structure the implementation process appropriately (3) the variables outside the law affecting the implementation (Mazmanian and Sabatier, 1983; cited Nugroho (2014). According to Edward III, (1980) that success of effective policy implementation is influenced by: (1) communication, (2) resources, (3) disposition, and (4) bureaucratic structure. Adam Smith (1973) cited Islamy (2001) that implementation of the policy is influenced by four variables, namely: (1) Idealized policy, (2) Target groups, (3) Implementing organization, dan (4) Environmental factors.

\subsection{Waste Management}

Law of the Republic of Indonesia Number 18 Year 2008 on Waste Management. In Article 1 paragraph (1) it is stated that the waste is a residual activity of human and / or natural process in the form of solid. Relevant opinions argued that waste generally comes from activities carried out by humans including industrial activities (Azwar, 2009).The relevant opinion is explained that waste is to a large extent subjective in meaning as a substance can only be regarded as a waste when the owner labels it as such. This is particularly true because one individual may regard a substance as a waste, while another may view the same substance as a resource. It is agreed that wastes is a direct result of human interaction and activities (Amasuomo \& Baird, 2016).

Waste management is a systematic, thorough, and continuous activity that includes waste reduction and handling. Waste management is organized based on the principle of responsibility, the principle of sustainability, the principle of benefit, the principle of justice, the principle of consciousness, the principle of togetherness, the principle of safety, the principle of security, and the principle of economic value (Azwar, 2010). Waste management is all the activities undertaken in handling waste since inflicted up to the final disposal. Waste management involves the control of waste generation, waste collection, transfer and transport, processing and final disposal (Kartikawan, 2007). Waste management involves a process whereby wastes are collected, transported and disposed of in the best possible way of limiting or eliminating the harmful effect of wastes (Amasuomo \& Baird, 2016).

Waste management aims to improve public health and environmental quality and make waste as a resource. Everyone must manage household waste in an environmentally sound way. Specific waste management is the responsibility of the Government (Post, 2005). In general, waste management in urban areas is done through 3 stages of activities, namely: collection, transportation and final disposal (Aboejoewono, 2005).

Based on this opinion, the waste management is not only as a process or activity that is implemented systematically and systematically integrated, but waste management is also associated with the support of resources such as human resources, transportation facilities, costs and so on. Thus, waste management is not only collecting, transporting and disposing but also related to efficiency and effectiveness in planning, organizing the implementation and supervision of waste management activities to achieve the realization of cleanliness, public health and environmental quality.

Waste management in an area will bring influence to the society and environment of the area itself that is (1) positive influence, good waste management will give positive impact to society and its environment, (2) negative influence, poor waste management can give influence negative for health, the environment, and for the socio-economic and cultural life of the community (Kartikawan, 2007).

\subsection{Obstacles in the Policy Implementation of Waste Management}

Factors that influence waste management are (1) community factor, (2) waste factor, meaning that type of waste can be solid, liquid and gas so that can influence waste management system. (3) organizational or management factors (4) economic factors. (5) legal factors. (6) low knowledge. (7) consciousness. (8) community participation (azwar, 2010). Factors affecting waste management include: (1) socio-political (2) demographic 
social aspects (4) land existence for waste shelters, (5) finance, (6) the existence of non-governmental organizations (NGOs) and (7) coordination among related agencies in the prevention of environmental or waste issues (Suarna, 2008). Urban waste management also has the driving and inhibiting factors in an effort to increase community participation in waste management. Inhibiting factors in waste management are the level of education, the placement of in-house waste, the presence of scavengers, the action of cleanliness, the existence of regulations on waste and law enforcement (Nitikesari (2005).

\section{Research Method}

This research uses qualitative approach. That the paradigm of qualitative research is constructed as one research strategy that usually emphasizes words rather than quantification in data collection and analysis, emphasizes an inductive approach to the relationship between research theories, but emphasizes the placement of the theory or participation of theory (Creswell, 2009 and Silalahi, 2009). Qualitative research method is a research method used to examine the condition of natural objects, where researchers are as a key instrument, data collection techniques are done by triangulation (combination), data analysis is inductive, and qualitative research results emphasize the meaning of generalization (Sugiyono, 2010).

The research on the policy implementation of waste management is implemented in Konawe Regency by establishing 4 (four) districts as the locus of waste collection. The informant of this research is the employee of Konawe Regency Living Environment Service with details as follows: 1 person (sector head of waste management), 1 person (section head of waste management), 1 person (Unit head of waste management), 1 person (section head environmental maintenance), 1 person (field supervisor), 1 person (driver), 1 person (employee), 1 person (secretary of service), and 1 person (Head of Environmental Office). While the informants from the community set as many as 4 (four) people with details as follows: 1 people (from Unaaha sub-district), 1 people (from Wawotobi district), 1 people (from Uepai district) and 1 people (from Tongauna district).

Informants used research on the policy implementation of waste management in Konawe Regency determined by purposive sampling. The informants in this study were determined by consideration of competence, authority, ability and knowledge of informants to provide data relevant to the policy implementation of waste management in Konawe Regency.

Technique of collecting research data is done by in-depth interview, observation and document study. The research instruments used in this research are interview guides, field notes and researchers themselves. Data analysis using interactive analysis model (Miles and Huberman, 1992, and Silalahi, 2009).

\section{Results and Discusion}

\subsection{Policy Implementation of Waste Management in Konawe Regency}

\subsubsection{Communication in the Policy Implementation of Waste Management}

In the policy implementation of waste management in Konawe Regency, communication is very important for leaders and subordinates to achieve the goals to be successful. This is in line with the opinion of the informants who stated that: "... as the leader of Konawe Regency Environmental Office, we always provide information regarding the implementation of waste management policy. The purpose of such communication is to provide information to employees or implementers in order to understand the purpose of waste management policy". Informant opinion that: "... we always convey information to the workers so that discipline in transporting waste, so that the volume of work within one working day can be achieved". Communication from above or leadership is very important in the policy implementation of waste management in Konawe Regency.. The purpose of communication is to provide the same understanding to the implementers so that the duties and responsibilities in the implementation of waste management policies can be achieved.

Communication as a factor that can determine the successful policy implementation of waste management in Konawe Regency. Communication among employees in implementing waste management policies is very important, as revealed by informants that: ".... In implementing the waste management policy, we always communicate with each other so that the process of selecting, collecting and transporting, final disposal and processing can be accomplished in accordance with the planning".. One of the informants also stated that: "... in implementing the waste management policy we always communicate with the leader or supervisor. The following informants stated that: "... as a waste management unit in the field, we also report to the management of waste management every day, week and month". Through communication all activities in waste management can be submitted to employees or leaders so there is a common vision in the policy implementation of waste management in Konawe Regency. Thus communication is very important so that the essence of the policy implementation of waste management that realize cleanliness, improve public health and improve the quality of 
the environment can be achieved. Therefore, the context of communication in the policy implementation of waste management is to realize the similarity of opinions from the leadership to the level of implementers of the work program in the policy implementation of waste management in Konawe Regency.

\subsubsection{Resources in the Policy Implementation of Waste Management}

In implementing the waste management policy in Konawe District, the resource factor is very important. It is relevant that informant opinion that: ".... In the implementation of waste management is supported by a number of employees who perform activities ranging from planning, implementation, organizing and supervision or evaluation". In waste management can be accomplished because of the sufficient number of employees, it is in accordance with the informant's statement that: "... .implementation of waste management policy is supported by equal number of employees according to their skills and skills". The next informant stated that: "the number of waste managers are 8 drivers, 40 workers, 8 supervisors, 7 waste managers, and 3 final disposal workers". Another informant stated that: "...the facilities and infrastructure used in waste management such as waste cars are 8 units, there are 10 units of waste and the trash bin is 121 units although still lacking but can support the collection, transportation and disposal of waste to the dump end to be processed. In addition, there are office facilities such as computers for reporting activities ".

One of the resources in the policy implementation of waste management in Konawe Regency is information. Informant's opinion that: "... much of the information we provided from the leadership, so that this policy can be implemented effectively". The policy implementation of the waste management can be accomplished because the authority is granted to the implementer, in the opinion of the informant that: ".... Waste management policy can be implemented due to the authority given to us. The authority given to implementers in the implementation of waste management policies can support the achievement of waste management.

From these facts it can be seen that resources such as the availability of employees, supporting facilities such as waste cars, waste motor, and waste cans, enough information is very important in the implementation of waste management policies. In addition, there is support for the economic, political, social and cultural environments, and authority given from the leadership.

\subsubsection{Disposition in the Policy Implementation of Waste Management}

Policy implementation of waste management in Konawe Regency need disposition from the leadership, subordinates, supervisors and workers. This fact is relevant to the informant's opinion that: "... we as the leadership element strongly support the policy of waste management aimed at creating beauty, hygiene, public health and environmental quality". The facts revealed are relevant to the informants' opinion that: "... we as subordinate employees support the policy implementation of waste management in Konawe Regency. Thus it can be seen that the policy implementation of waste management in Konawe Regency there is support attitude from the leadership and subordinate employees.

Policy implementation of waste management is supported by the attitude of the supervisor of waste management. According to informants that: "... we as supervisors support the policy implementation of this by doing the job well". Other informants also argued that: "... we as drivers of waste cars support the implementation of waste management, by the way every day we collect, transport and dispose of waste to a predetermined location". This fact proves that supervisors and workers have an attitude or disposition in the policy implementation of waste management in Konawe Regency.

\subsubsection{Bureaucratic Structure in the Policy Implementation of Waste Management}

In the policy implementation of the waste management in Konawe Regency, there has been support for bureaucratic structures. According to informants that: "... in waste management there is an organizational structure to facilitate coordination with relevant agencies and internal coordination at the Konawe District Environmental Office". The next informant stated that: ".... Every employee in the waste management unit works according to standard operating procedures (SOPs) and performs tasks according to their positions within the organizational structure that the leader has set". Thus, in the policy implementation of waste management policy in Konawe Regency supported bureaucratic or organizational structure to facilitate the implementation of tasks and coordination among employees and work units. Without any coordination, the waste management policy can not be effective. This is relevant to the study (Amasuomo \& Baird, 2016) finding that the lack of coordination and expertise on waste management issues by the environmental agencies and other organs of Government promotes inefficiency. That the bulk of the problems relating to waste management in the country Nigeria is as a result of the unavailability of proper waste management policy.

Policy implementation of waste management in Konawe Regency is empirically supported by four main factors: 
communication, resources, disposition and bureaucratic structure. The four factors are still weakness in the implementation so that the expected goal is less effective during two years policy implementation of waste management. Therefore, to realize the cleanliness, public health and environmental quality of the implementers must work hard. This research results are relevant to the Murdiningsih (2014) finding that the implementation process of waste management policy in Manado City Sanitation Department is viewed from the communication aspect (between policy organizers and target groups), resources (availability of human and financial resources), disposition), bureaucratic structure (mechanism and organizational structure of implementing / division of tasks and responsibilities). The result of this study is relevant to the opinion of Edward III (1980) that the factors determine the effectiveness of policy implementation are communication, resources, disposition and bureaucratic structure.

\subsection{Obstacles in the Policy Implementation of Waste Management}

The study found obstacles in the implementation of waste management policy in Konawe Regency as follows:

\subsubsection{Facility}

In the policy implementation of waste management in Konawe Regency, the facilities used to collect, transport and dispose of waste greatly affect the success of waste management. According to the informant's opinion that: '... the available facilities such as waste cans are still very low, so that many people are dumping waste instead of waste dumps'. The results of the interview illustrate that waste bins are less available so a lot of waste can not be collected, transported and disposed of. This is one of the obstacles in waste management in Konawe Regency.

In the transportation of waste is needed such as motor to transport waste around settlement which is difficult to reach waste car. According to informants that: ... constraints in waste collection around the settlements of the motor waste is still lacking so much waste that can not be collected ". The informant's opinion proves that one of the obstacles in waste collection is the waste motor is still less available in the residential area to collect the waste and taken to the waste.

The next informant argued that: ... the existing waste car is not capable of transporting all the rubbish contained in 4 (four) districts, a lot of waste can not be transported to the final waste disposal site because the existing waste car is only 8 units ". The informant's opinion proves that in the waste management in Konawe Regency, there are still obstacles that the waste car is still lacking so there is still a lot of waste that can not be collected, transported and disposed of to the final waste disposal.

The facts are revealed in line with the opinion of the Head of the Environment Office of Konawe Regency which stated that: ... indeed in waste management in Konawe Regency one of the obstacles found is the waste car that is still lacking so much waste that can not be transported every day. Currently, only 6 units of waste cars are in good condition and 2 units are not feasible to use (old). Hopefully next year waste cars can be added to 10 units". Informant's opinion proves that the obstacles in the implementation of waste management policy because the facilities used to collect waste such as waste, waste motor and waste car is still lacking. Thus the lack of facilities in waste management can lead to ineffective and efficient waste management.

\subsubsection{Condition of Work Area}

Obstacles in the policy implementation of waste management in Konawe Regency is the condition of a very wide area of work in the collection and transport of waste. a vast work area with short working hours and few waste cars can affect effective and efficient waste management.

According to the informants that: ".... The extent of the area we serve to transport waste there are 4 (four) districts. This is a barrier because it is not balanced with the number of waste trucks. Furthermore informants stated that: ".... we as workers (car drivers) have problems in transporting waste because the work area is too wide ". Informant's opinion as evidence that in the waste management there are obstacles from the condition of the vast work area that is not supported by adequate facilities.

The facts are in line with the opinion of the Section Head of Waste Management that: ... "We recognize that one of the obstacles in waste management in Konawe Regency is the vast work area while the number of vehicles is only 8 units. Due to the vastness of the working area, a lot of waste can not be collected, transported and disposed of to landfills. " The informant's opinion is a proof that there are obstacles in waste management in Konawe Regency that is the area of work to transport waste.

The facts revealed are relevant to the opinion of Konawe Regency Head of Environment Office: "... a vast work area becomes an obstacle for employees to collect, transport and dispose of waste. the area of work with the number of waste cars available is very unbalanced ". Informant's opinion proves that one of the obstacles in 
waste management in Konawe Regency is the area of work so that a lot of waste can not be collected, transported and disposed of.

Based on the facts revealed, the policy implementation of waste management policy in Konawe Regency is still a barrier from the aspect of the condition of the working area is very wide. This is the cause of ineffective and efficient policy implementation of waste management in Konawe Regency.

\subsubsection{Community Awareness}

Policy Implementation of waste management in Konawe Regency, can be successful if supported by community awareness. Community awareness in waste management ie the community does not dispose of waste disembarang place but must be thrown in the trash. Communities should have good behavior by disposing of waste in accordance with the provisions set by the government or waste management unit. Related to this one informant stated that: "... sometimes we throw the waste not in the trash bin because the trash is far from our house". One informant stated that: ... "Today people still often throw waste in free space". Informant's opinion proves that in the policy implementation of waste management found barriers from community awareness aspect is still lacking. Furthermore informants from the community stated that: "... we sometimes throw the waste out freely because the waste dump in our area does not yet exist". Informant's opinion proves that there are obstacles in the policy implementation of waste management in Konawe regency that is community awareness is still lacking. Citizens often throw waste freely and do not sort waste.

One employee who did the waste collection stated that: "... when we collect and haul waste, we still find a lot of waste that is not dumped in waste disposal". the opinion proves that public awareness to dispose of waste properly is lacking. The facts are relevant to the informant's opinion that: ... in general the behavior of people to dispose of waste properly is lacking. In addition, indeed the existing trash bin we now admit is still lacking, so that people lack awareness to dispose of waste properly". The revealed facts prove that in the policy implementation of waste management in Konawe Regency, there are found barriers that the community awareness is still lacking.

The fact of the lack of community awareness in waste management in Konawe Regency is in line with the research of Velumani, et. al, (2009) found that the community awareness in the segregation of the waste fraction ensures the successful implementation of this system. The research Fombe \& Ntani (2012) in Cameroon finding that there is need for greater awareness by the local population and planning authority to ensure environmental safety through safe disposal and reuse of the materials. Responsibly managing waste from construction sites is a vital component of a sustainable environment and economic development as part of a global drive towards sustainable cities. Research results Said and Noor, (2015) find that the factors impeding the policy implementation of waste management are low public awareness and human resources.

Thus, one of the obstacles in the policy implementation of waste management in Konawe Regency is the lack of community awareness. People still tend to dispose of waste freely instead of a trash can that has been provided by the government or waste management unit.

\subsubsection{Community Participation}

Policy Implementation of waste management in Konawe Regency, it is very necessary for the community participation so that waste management can succeed. Community participation is needed from waste segregation, how to dispose of waste, can process, and reuse waste and collect waste that has economic value or selling value. According to informants domiciled in Unaaha district that: ... . for this, the waste is discarded without being sorted, we also do not recycle and we have not been able to process waste ". Informant's opinion proves that people only dump waste without sorting and not recycling. Thus, community participation is still lacking in waste management.

Informants from Tongauna District stated that: "... our household trashes just throw away without separating solid waste such as paper, gardus, plastic and glass. All we throw in the trash bin ". Informant's opinion proves that community participation in waste management is lacking. Communities do not utilize waste that has economic value such as paper and gardus but all thrown away. Informants from Wawotobi district also argued that: ... "The waste from our homes has not been able to process it to be beneficial but all thrown away". While informants from Uepai District stated that: ... . for this we have not been able to perform waste processing independently ".. This fact proves that there is still less participation in waste management such as sorting that can be recycled or processed to have the selling value or economic value . In addition, the community participation in processing waste independently is still lacking. Thus, one of the obstacles in policy 
implementing the waste management in Konawe Regency is the lack of community participation. The community has not been able to do waste processing independently and use the waste to fertilize and recycle.

\subsubsection{Low Knowledge}

In the policy implementation of waste management in Kabupaten Konawe, as one of the obstacles is the low knowledge of the community in the solid of waste management. This fact is relevant to the opinion of the informants that "... from our observation as supervisor, we still find people who throw waste indiscriminately" . Furthermore, one informant stated that: "... we still often find waste that is discarded freely. People still have bad behavior in taking out waste ". This fact proves that the level of public knowledge of hygiene and environmental health is still minimal. This is relevant to the research Khajuria, \& Matsui (2011) in India find that literacy rate significantly determines the eco-efficiency of Indian states. This suggests importance of education as domestic policy to improve waste management. Therefore, awareness in waste management can be observed from the level of education, such as the research Mallak, et al (2014) in Malaysia find that awareness drives waste management through dispersal of salient information, ensuring human capability. Education will have a stronger and lasting effect as it encourages participation. Also, education promotes creative responses to any shortcomings. An analysis result reveals an average in lack of awareness among employee, belief, partnership, trained staff and expertise and manpower to run the program in the industrial categories. Lack of behavior and awareness of clean and quality environments are still the findings of studies in Konawe Regency. The research Mallak, et al., (2014) in Malaysia find that lack of environmental ethics and awareness contribute to the failure of solid waste management plans. Therefore, instilling information on waste issues will go a long way. This includes basic information about solid waste minimization, legal information, technical information and accurate knowledge about waste minimization.

The facts informed by informants can be seen that in the policy implementation of waste management in Konawe Regency there are still obstacles such as facilities, working area conditions, public awareness, community participation, and low knowledge. Research Nitikesari (2005) in Indonesia find that the obstacles factor of waste management comes from the community (as external factor) and from the manager itself or related institution (as internal factor). The research Muchangos, etal, (2015) in Maputo City In Mozambique find that barriers to its implementation according to seven fundamental policy instruments: legislation and regulation; voluntary agreements; economic instruments; education and influence over behavioral change; monitoring, information and performance assessment; choice of technology; and community linkages. Problems or obstacles in the policy implementation of waste management in Kabupaten Konawe is of relevance to the research Amasuomo \& Baird, (2016) find that solid waste management is a major concern in the country. Inadequate environmental policies and legislations, low level of environmental awareness, poor funding and inappropriate technology, corruption and unplanned development were some of the challenges facing solid waste management in the country.

Thus, the policy implementation of the waste management in Konawe Regency emphasizes the four main factors of communication (internal and external), resources (staff / supervisors, workers, and waste hauling facilities, waste shelters), the attitude of the implementers. The combination of these four factors has not been effectively implemented to improve hygiene, public health and environmental quality in Konawe Regency. Therefore, the implementers still need to work hard to achieve the goal of policy implementation of waste management in Konawe Regency. Therefore, according to (Kartikawan, 2007) that waste management in one area will bring influence to society and environment of the area itself, that is positive influence if done well and negative influence if not done waste management.

\section{Conclusion}

The result of this study concluded that in the policiy implementation of waste management in Konawe Regency, has been there communication from top (superior) to bottom (subordinate) and from bottom to top. The essence of communication is to convey various in relation to information on waste management policy. Policy implementation of waste management in Konawe Regency has been supported by resources such as employees, staff, supervisors and workers according to their expertise. In addition, supported facilities such as cars and motorbikes, waste collection and landfills but still minimal. In the policy implementation of waste management policies supported by the disposition or attitude of the leadership, subordinates, supervisors and workers to take the initiative in waste management. Furthermore, policy implementation of waste management in Konawe Regency has existing bureaucratic or organizational structure. The implementers work according to SOP and based on their position in the bureaucratic or organizational structure.

Empirically the policy implementation of waste management in Konawe is not perfect yet, because there are still 
obstacles such as lack of facilities, working area condition, public awareness, community participation and low knowledge of the community, so the implementers still need hard work to improve hygiene, public health and environmental quality in Konawe Regency.

Thus, further research is needed in the region or anywhere in related with the policy implementation of the waste management as a scientific contribution (practical and theoretical). Finally, hopefully the results of this study will benefit other researchers and local governments everywhere. Specifically for the Regional Government of Konawe Regency, Southeast Sulawesi, Indonesia, hopefully the results of this study will be useful in improving the policy implementation of waste management in Konawe Regency in the future.

\section{References}

Aboejoewono, A. (2005). Waste Management Towards Environmental Sanitation and its Problems; Jakarta Area as a Case. Jakarta.

Amasuomo, E., \& Baird, J. (2016) Solid Waste Management Trends in Nigeria. Journal of Management and Sustainability, 6(4), 35-55. http://dx.doi.org/10.5539/jms.v6n4p35

Amasuomo, E., \& Baird, J. (2016). The Concept of Waste and Waste Management. Journal of Management and Sustainability, 6(4), 88-96. http://dx.doi.org/10.5539/jms.v6n4p88

Azwar, A. (2009). Introduction to Environmental Health Sciences, Mutiara Sumber Widya. Jakarta.

Creswell, J. W. (2009). Research, Design Qualitative, Quantitative and Mixed Methods Approaches (3rd ed.). Sage Publications, Thousand Oaks Chalifornia.

Dunn, W. N. (1994). Introduction to Public Policy Analysis, Edisi Kedua, Yogyakarta: Gadjah Mada University Press.

Dye, T. R. (2005). Understanding public policy. New Jersey: Pearson Education.

Edward III, G. C. (1980). Implementing Public Policy. Congressional Quarterly Press, Washington.

Ezebilo, E. E., \& Animasaun. E. D. (2011). Economic Valuation of Private Sector Waste Management Services. Journal of Sustainable Development, 4(4), 38-46.

Fombe, L. F., \& Ntani, M. D. (2012). Building and Endangering Urban Landscapes: the Case of Construction Wastes in Bamenda Cameroon. Journal of Sustainable Development, 5(10). http://dx.doi.org/10.5539/jsd.v5n10p60

Giusti, L. (2009). A review of waste management practices and their impact on human health. Waste Management, 29(8), 2227-2239. https://doi.org/10.1016/j.wasman.2009.03.028

Grindle, M. S. (Ed.). (1980). Politics and policy Implementation in the Third World. New jersey: Princetown University Press.

Ikhlayel, M., Higano, Y., Yabar, H., \& Mizunoya, T. (2016). Introducing an Integrated Municipal Solid Waste Management System: Assessment in Jordan. Journal of Sustainable Development, 9(2), 43-53. http://dx.doi.org/10.5539/jsd.v9n2p43

Islamy, M. I. (2001). Principles of Government Policy Formulation. Jakarta, Bumi Aksara.

Jalil, M. A. (2010). Sustainable Development in Malaysia: A Case study on Household Waste Management. Journal of Sustainable Development, 3(3), 91-102.

Kartikawan, Y. (2007). Waste Management, J. Lingkungan Hidup, Yogyakarta.

Khajuria, A., \& Matsui, T. (2011). Economic Growth Decoupling Municipal Solid Waste Loads in Terms of Environmental Kuznets Curve: Symptom of the Decoupling in India. Journal of Sustainable Development, 4(3), 51-59.

Law of the Republic of Indonesia Number: 18 of 2008 About Waste Management.

Mallak, S. K., Ishak, M. B., Mohamed, A. F., \& Abdullah., S. (2014). Barriers to Practice of Non-Hazardous Solid Waste Minimization by Industries in Malaysia. Journal of Management and Sustainability, 4(1), 154-162. http://dx.doi.org/10.5539/jms.v4n1p154

Manaf, L. A., Hassan, B., \& Noor, E. A. B. (2008). UrusSisa: An Intelligent System for Integrated Solid Waste Management. Journal of Sustainable Development, 1(2), 39-52.

Mazmanian, D. H., \& Sabatier, P. A. (1983). Implementation and Public Policy. New York: HarperCollins. 
Miles, M. B., \& Huberman, A. M. (1992). Qualitative Data Analysis. Translation by: Tjetjep Rohendi Rohidi. Jakarta: Universitas Indonesia Press.

Moersid, M. M. (2004). The concept of National Action Plan for Waste Management in the Framework of the Millennium Development Goals. Semarang: In the Integrated Waste Management Study Events.

Muchangos, L. D., Tokai, A., \& Hanashima, A. (2015). Application of the Delphi Method to the Identification of Barriers to a Waste Management Policy in Maputo City, Mozambique. Journal of Sustainable Development, 8(6), 146-157. http://dx.doi.org/10.5539/jsd.v8n6p146

Murdiningsih. (2014). Implementation of Waste Management Policy at Manado City Sanitation Department. Journal of Public Administration. Retrieved December 23, 2016, from https://www.google.co.id/?gws_rd=cr\&ei=EMFjWNiINIrjvASihLjgAw\#q=tesis+efektivitas+implementasi + kebikan+pengelolaan+sampah

Nitikesari, P. E. (2005). Analysis of Participation Level of the Community in Handling Waste Independent in Denpasar City. Thesis Master of Post Graduate Program of Udayana University, Denpasar.

Nugroho, R. (2014). Public Policy (5th ed.). PT. Elex Media Komputindo, Jakarta.

Nuzuli, O. F., Gani, Y. A., Pratiwi, R. N., Hanafi, I., \& Fitrianto, A. (2015). Policy Implementation of Local Communities Development-Based Waste Management in Banjarbaru, South Kalimantan, Indonesia. Asian Social Science, 11(18), 279-288. http://dx.doi.org/10.5539/ass.v11n18p279

Onu, B., Surendran, S. S., \& Price, T. (2014). Impact of Inadequate Urban Planning on Municipal Solid Waste Management in the Niger Delta Region of Nigeria. Journal of Sustainable Development, 7(6), 27-45. http://dx.doi.org/10.5539/jsd.v7n6p27

Parsons, W. (2005). Public Policy, Introduction to Theory and Practice of Policy Analysis, translation: Tri Wibowo Budi Santoso, Prenada Media, Jakarta.

Pasang, H. (2005). Regional and Integrated Waste Management. Retrieved from http://www.Sarwono.net

Regional Regulation of Konawe Regency Number 30 Year 2015 About Waste Management.

Said, L.O., Mardiyono, A., \& Noor, I. (2015). Implementation of Baubau City Waste Management Policy, Thesis. Journal of Social Science and Political Science, 4(1), 53. Retrieved December 23, 2016, from www.Publikasi.Unitri.Ac.Id

Silalahi, U. (2009). Social Research Methods, Refika Aditama, Bandung.

Singh, R. K., Yabar, H., Mizunoya, T., Higano, Y., \& Rakwal, R. (2014). Potential Benefits of Introducing Integrated Solid Waste Management Approach in Developing Countries: A Case Study in Kathmandu City. Journal of Sustainable Development, 7(6), 70-83. http://dx.doi.org/10.5539/jsd.v7n6p70

Suarna, I. W. (2008). Model of Urban and Rural Trash Problems Problems, Universitas Udayana.

Sugiyono. (2010). Understanding Qualitative Research, Alfabeta, Bandung.

Tachjan. (2008). Policy Implementation of Public. Bandung: AIPI.

Velumani, A., Saravanan, K., Kannadasan, T., \& Ganesan, K. (2009). Design of Temporary Storage of Municipal Solid Waste and Its Impact on Global Warming -A Case Study. Journal of Sustainable Development, 2(3).

Wahab, S. A. (2008). Policy Analysis; From Formulation to Policy Implementation of State Jakarta: Sinar Grafika

Winarno, B. (2007). Policy Public: Theory and Process. Yogyakarta: Media Pressindo.

\section{Copyrights}

Copyright for this article is retained by the author(s), with first publication rights granted to the journal.

This is an open-access article distributed under the terms and conditions of the Creative Commons Attribution license (http://creativecommons.org/licenses/by/4.0/). 